\title{
Comparative of oil content from salt cyclothems in Qianjiang depression, Jianghan Basin, Central China and its indication
}

Tingting CAO ${ }^{1}$, ERshe XU ${ }^{1}$, ZHIMING Li $^{1}$, MAOWEN Li ${ }^{1}$

${ }^{1}$ SINOPEC Wuxi Institute of Petroleum Geology

Qianjiang depression is a typical salt lake basin with abundant salt cyclothems in Eocene Qianjiang Formation. The fine-grained cyclothems between salt layers have great potential of shale oil resources. The current work shows not all fine-grained cyclothems were rich in shale oil. 49 core samples from the different oil content cyclothems were selected based on the Rock-Eval S1 values acquired from well site pyrolysis of closed-frozen-crushed.

The results show that the samples from high oil content cyclothems were developed in the high salinity, anoxic reduction and strongly delaminating water body environment, which is beneficial to the enrichment and preservation of organic matter, While the cyclothems with low oil content were formed in the weak oxidation environment of brackish water, the enrichment and preservation condition were relatively poor. The microscopic reservoir characteristics show that there were great differences in lithofacies among cyclothems with different oil contents. The laminated argillaceous dolomite facies has developed pores and good connectivity, was rich in oil content, while the calciumbearing mirabilite dolomitic mudstone facies had poor oil content. We also found that the oil content varies, under the under the affecting of maturity, with free hydrocarbons increasing and hydrocarbon composition varying. However, the extremely high oil content of the upper laminated argillaceous dolomite facies revealed that the quality of reservoir performance was the key factor for oil content of shale oil. 